\title{
Analisis Kemampuan dalam Menyelesaikan Soal Cerita Menggunakan Pendekatan Prolem Solving pada Materi Perkalian di Kelas III SDN 1 Sayan
}

\author{
R Putri ${ }^{1, a}$, Y Sarassanti ${ }^{2, b}$, A Tirsa ${ }^{1, c}$ \\ ${ }^{1}$ Pendidikan Guru Sekolah Dasar, STKIP Melawi \\ ${ }^{2}$ Pendidikan Matematika, STKIP Melawi

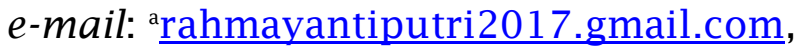 \\ byumisarassanti@yahoo.co.id, chcharineannora@yahoo.co.id
}

\begin{abstract}
The purpose of this researc was to describe (1) students ability to complete story test before usedproblem solving approach. (2) students ability to complete story test after used problem solving learning. (3) the significant difference of students ability to complete story test before and after used problem solving approach. This researc was to pre experimental design, and this design is one group pretest-posttest . this research did to the thre $e^{\text {th }}$ grade students at SDN 1 Saya, there have 24 students with 14 boys and 10 girls. Data analysis on this research are normality test, test of homogenity, paired sample t-test, and n-gain test. The result of this research: (1) Students ability to complete story test before used problem solving approach look on the pretest shown that value average of the students are 42. (2) Students ability to complete story test after used problem solving approach look on the pretest shown that value average of the students are 75.83. (3) It shown that signifanct difference of students ability to complete story test before and after used problem solving approach.
\end{abstract}

Keywords: Ability to complete story test, problem solving.

\begin{abstract}
Abstrak
Penelitian ini bertujuan untuk mendeskripsikan: (1) Kemampuan siswa dalam menyelesaikan soal cerita sebelum menggunakan pendekatan problem solving. (2)Kemampuan siswa dalam menyelesaikan soal cerita sesudah menggunakan pendekatan problem solving. (3)Apakah terdapat perbedaan signifikan kemampuan siswa dalam menyelesaikan soal cerita sebelum dan sesudah menggunakan pendekatan problem solving. Jenis penelitian ini adalah pra eksperimen (pre experimental design) dengan bentuk one group pretest-posttest design. Penelitian ini dilakukan pada siswa kelas III SDN 1 Sayan yang berjumlah 24 orang, terdiri dari 14 laki-laki dan 10 perempuan. Analisis data dalam penelitian ini menggunakan uji normalitas, uji homogenitas, uji hipotesis (uji-t), dan uji n-gain. Hasil Penelitian : (1)Kemampuan siswa dalam menyelesaikan soal cerita sebelum menggunakan pendekatan problem solving yang terlihat dari pretest menunjukkan bahwa rata-rata nilai yang diperoleh
\end{abstract}


siswa adalah 42. (2)Kemampuan siswa dalam menyelesaikan soal cerita sesudah menggunakan pendekatan problem solving yang terlihat dari posttest menunjukkan bahwa rata-rata nilai yang diperoleh siswa adalah 75.83 (3) Berdasarkan hasil uji-t, diketahui bahwa terdapat perbedaan pada kemampuan siswa menyelesaikan soal cerita antara sebelum dan sesudah menggunakan pendekatan problem solving.

Kata Kunci: Kemampuan menyelesaikan soal cerita, Problem Solving.

\section{[1]. PENDAHULUAN}

Perkalian merupakan salah satu materi yang ada dalam pembelajaran matematika. Perkalian di SD sudah dipelajari sejak kelas I. Pada kelas III SD, perkalian mulai menjadi salah satu topik yang dianggap sulit oleh siswa. Perkalian di kelas III sudah mencapai perkalian dengan hasil tiga angka, jika siswa belum mempunyai kemampuan dalam berhitung, maka perkalian akan sulit dipahami oleh siswa. Mutaqin menyebutkan salah satu faktor yang menyebabkan pelajaran matematika tampak sulit karena banyaknya hitungan yang melibatkan angka dan logika [1]. Perkalian termasuk salah satu materi dalam matematika di SD yang sulit dipahami oleh sebagian siswa.

Hasil pengamatan peneliti saat melakukan Praktik Pengalaman Lapangan di SDN 1 Sayan selama 3 bulan, yaitu terhitung dari tanggal 23 September 2017 sampai dengan 23 November 2017, peneliti menemukan bahwa dalam kegiatan belajar mengajar khususnya dalam mata pelajaran matematika, siswa kesulitan dalam menyelesaikan soal cerita. Kesulitan tersebut berpengaruh terhadap nilai siswa, hal ini dapat dilihat berdasarkan data nilai ulangan siswa yang masih rendah. Siswa juga kurang memahami materi yang disampaikan oleh guru, karena metode yang digunakan guru dalam mengajar kurang bervariasi dan menyebabkan siswa merasa bosan serta lebih senang bermain sendiri, khususnya pada siswa laki-laki. 
Menurut Ratna, Kemampuan memiliki tiga aspek, yaitu kognitif, afektif, dan psikomotorik [2]. Kemampuan kognitif dan afektif adalah kemampuan yang ingin peneliti tingkatkan pada siswa kelas III untuk dapat menyelesaikan soal cerita pada materi perkalian. Untuk menganalisis kemampuan siswa dalam menyelesaikan ini, peneliti menggunakan pendekatan problem solving yang akan diterapkan pada materi perkalian di kelas III. Dengan menerapkan pendekatan problem solving, kegiatan belajar melalui pemecahan masalah (problem solving) bermanfaat untuk mengembangkan kemampuan berpikir alternatif, dan kemampuan mengambil keputusan berdasarkan alternatif tersedia[3].

Menurut Depdiknas, komponen penting yang harus dimiliki peserta didik adalah kemampuan dalam memecahkan masalah [4]. Solusi pemecahan masalah menurut Polya melalui empat langkah tahapan yaitu (a) understanding the problem (memahami masalah), (b) difising out the plan (merencanakan masalah), (c) carrying out the plan (melaksanakan rencana penyelesaian), (d) looking back (memeriksa proses dan hasil penyelesaian).

Berdasarkan hasil penelitian yang sebelumnya telah dilakukan oleh Pramirtha [5] dengan judul "Model Pembelajaran Problem Solving Terhadap Kemampuan Menyelesaikan Soal Cerita Matematika bagi Siswa Tunanetra", yang mana hasil penelitian tersebut menunjukkan bahwa terdapat perkembangan selama intervensi pada anak dalam menyelesaikan atau mengerjakan soal pecahan setelah guru menggunakan problem Solving. Maka peneliti kemudian merasa termotivasi untuk melakukan penelitian dengan judul "Analisis Kemampuan dalam Menyelesaikan Soal Cerita Menggunakan Pendekatan Problem Solving pada Materi Perkalian di Kelas III SDN 1 Sayan".

Menurut Polya juga mengartikan "pemecahan masalah sebagai suatu usaha mencari jalan keluar dari suatu kesulitan guna mencapai suatu tujuan yang tidak begitu mudah segera dapat dicapai" [6]. Polya juga menggaris bawahi bahwa "untuk pemecahan masalah yang berhasil harus selalu disertakan upaya-upaya khusus yang 


\section{Hipotenusa}

dihubungkan dengan jenis-jenis persoalan sendiri serta pertimbanganpertimbangan mengenai isi yang dimaksudkan”. Konsep-konsep dan aturan harus disentesis menjadi bentuk-bentuk kompleks yang baru agar siswa dapat menghadapi situasi-situasi yang baru. Problem solving berdasarkan langkah-langkah Polya merupakan stategi yang tepat dalam membantu siswa menyelesaikan soal cerita dengan mudah. Polya mengemukakan ada empat langkah didalam memecahkan suatu masalah yaitu :
1) Mengerti terhadap masalah
2) Mempunyai rencana untuk menyelesaikan masalah
3) Mencoba untuk menjalankan masalah tersebut
4) Melihat kembali hasil yang telah diperoleh secara keseluruhan.

Pemecahan masalah dalam matematika adalah proses menemukan jawaban dari pertanyaan yang terdapat dalam suatu cerita, teks, tugastugas, dan situasi-situasi dalam kehidupan sehari-hari. Kemampuan pemecahan masalah merupakan kurikulum matematika yang sangat penting atau dapat dikatakan bahwa kemampuan memecahkan masalah merupakan hasil utama dari suatu proses pembelajaran. Pada saat siswa menemukan masalah, maka telah terjadi perbedaan keseimbangan dengan perbedaan awal.Suatu masalah dapat mengarahkan siswa untuk melakukan investigasi, mengeksplorasi pola-pola dan berpikir secara kritis Fauzan [6].

Menurut Pramirtha, soal cerita matematika sangat berperan penting dalam kehidupan sehari-hari peserta didik, karena soal tersebut mengedepankan permasalahan-permasalahan yang nyata sesuai dengan kehidupan sehari-hari [5]. Soal cerita sebagai bentuk evaluasi kemampuan peserta didik terhadap kosep dasar matematika yang telah dipelajari berupa soal penerapan rumus. Seseorang dapat dikatakan memiliki kemampuan matematika apabila terampil dengan benar menyelesaikan soal cerita. Soal cerita matematika bertujuan agar peserta didik berlatih dan berpikir secara deduktif, dapat melihat hubungan dan kegunaaan matematika dalam kehidupan sehari-haridan 
dapat menguasai keterampilan matematika serta memperkuat penguasaan konsep matematika.

Menurut Lencher, memecahkan masalah matematika adalah proses menerapkan pengetahuan matematika yang diperoleh sebelumnya kedalam situasi baru yang belum dikenal [7]. Dalam pembelajaran matematika, pemecahan masalah diwujudkan dengan soal-soal cerita matematika yang berkaitan dengan kehidupan sehari-hari.

\section{METODE PENELITIAN}

Jenis penelitian yang digunakan dalam penelitian ini adalah pre experimental dengan menggunakan pendekatan one grup pre-test and post-test design. Design ini bertujuan untuk mengetahui bagaimana kemampuan siswa dalam menyelesaikan soal cerita pada materi perkalian. Subjek dalam penelitian ini terlebih dahulu diberikan test awal (pretest) untuk mengetahui sejauh mana kemanpuan awal siswa. Setelah tes awal, selanjutnya diberikan kepada siswa perlakuan dengan menggunakan model pembelajaran problem solving. Setelah selesai pemberlakuan selanjutnya diberikan tes akhir (posttest) untuk mengetahui sejauh mana kemampuan siswa menyelesaikan soal cerita menggunakan model pembelajaran problem solving.

Penelitian ini dilaksanakan di SDN 1 Sayan, Kecamatan Sayan, Kabupaten Melawi pada semester genap tahun pelajaran 2017/2018. Penelitian ini dilaksanakan pada tanggal 24, 26, 30, dan 31 Mei 2018. Penelitian ini dilakukan dengan memberikan tes kemampuan pemecahan masalah menyelesaikan soal cerita materi perkalian.

Hasil dari tes tesebut kemudian dianalisis secara kuantitatif. Data kuantitatif diperoleh untuk mengetahui tingkat kemampuan pemecahan masalah menyelesaikan soal cerita pada siswa kelas III SDN 1 Sayan. Setelah dilakukan analisis data kuantitatif, siswa dikelompokkan berdasarkan kualifikasi tingkat kemampuan pemecahan masalah. Pada penelitian ini, langkah-langkah yang akan ditempuh adalah tahap persiapan, tahap pelaksanaan, dan tahap akhir. 
Tahap persiapan dilakukan dengan menentukan sekolah yang akan dijadikan tempat penelitian, melakukan observasi ke sekolah, menyusun perangkat pembelajaran (silabus, RPP, dan LKS) yang akan digunakan pada proses pembelajaran di kelas yang akan diberikan perlakuan atau tindakan.

Tahap pelaksanaan dilakukan dengan mengadakan validasi soal, melakukan uji coba soal, menghitung validitas, reliabilitas, daya pembeda, dan taraf kesukaran dari soal yang telah diuji coba, memberi tes awal (pretest), memberikan nilai pada tes awal (pretest), dan Memberikan perlakuan menggunakan model pembelajaran problem solving. Kemudian pada tahap akhir peneliti melakukan tes akhir (posttest), dan memberi nilai pada tes akhir (posttest). Setelah melaksanakan tahap persiapan, tahap pelaksanaan, dan tahap akhir, peneliti selanjutnya melakukan analisis terhadap data hasil penelitian.

Analisis terhadap data hasil penelitian dilakukan dengan menggunakan uji normalitas, uji-t, dan uji n-gain. Uji normalitas dalam penelitian ini dilakukan dengan menggunakan uji liliefors, sedangkan uji-t dalam penelitian ini menggunakan paired sample t-test.

\section{HASIL DAN PEMBAHASAN}

Hasil uji normalitas yang peneliti lakukan dengan berbantuan program SPSS, diketahui bahwa data hasil pretest dan postest siswa dinyatakan berdistribusi normal. Hal tersebut dikarenakan nilai signifikansi yang diperoleh lebih dari angka konstanta (0.05) yaitu pada 0.252 pada pretest dan 0.450 pada posttest. Setelah melakukan uji normalitas, peneliti kemudian melakukan uji homogenitas untuk mengetahui apakah data hasil penelitian memiliki memiliki varian yang sama atau tidak. Hasil uji homogenitas yang dilakukan dengan bantuan program SPSS menunjukkan bahwa nilai signifikansi yang diperoleh lebih dari angka konstanta yaitu $0.997>0.05$ sehingga peneliti membuat kesimpulan bahwa data hasil penelitian yaitu pada pretest dan postest memiliki varian yang sama atau homogen. 
Hasil uji-t dengan rumus paired sample t-test yang dilakukan dengan bantuan program SPSS, diketahui bahwa nilai signifikansi yang diperolah adalah 0.000 yang berarti angka tersebut kurang dari 0.05 sehingga $\mathrm{H}_{0}$ ditolak dan $\mathrm{H}_{\mathrm{a}}$ diterima. Jadi peneliti membuat kesimpulan bahwa terdapat perbedaan kemampuan siswa dalam menyelesaikan soal cerita pada sebelum dan sesudah menggunakan pendekatan problem solving.

Uji n-gain dalam penelitian ini dilakukan dengan berbantuan program microsoft excel. Uji ini dilakukan untuk mengetahui bagaimana perbedaan kemampuan siswa dalam menyelesaikan soal cerita antara sebelum dan sesudah diberikan perlakuan dengan menggunakan pendekatan problem solving. Hasil uji n-gain yang telah dilakukan dengan berbantuan microsoft excel, diketahui bahwa skor ngain yang diperoleh oleh siswa kelas III SDN 1 Sayan terkategori ratarata dan tinggi. Dengan demikian maka peneliti membuat kesimpulan bahwa setiap siswa mengalami peningkatan kemampuan dalam menyelesaikan soal cerita.

Berdasarkan hasil pretest dan posttest siswa, peneliti kemudian menghitung ketuntasan belajar siswa yang dapat dilihat pada lampiran halaman 116-117. Peneliti membandingkan nilai pretest dan posttest yang diperoleh siswa dengan standar atau kriteria ketuntasan minimal yang telah ditentukan pada mata pelajaran matematika yaitu 65. Dari perbandingan tersebut diketahui bahwa keseluruhan siswa pada pretest memperoleh nilai kurang dari kriteria ketuntasan minimal, sehingga dapat disimpulkan bahwa tidak ada seorang pun yang tuntas dalam pelajaran. Dari perbandingan tersebut juga diketahui bahwa pada posttest terdapat 21 siswa yang memperoleh nilai lebih dari 65, dan 3 siswa yang memperoleh nilai kurang dari 65. Sehingga peneliti membuat kesimpulan bahwa $87.5 \%$ siswa memperoleh ketuntasan belajar.

Berdasarkan penelitian relevan yang sebelumnya yaitu penelitian yang dilakukan oleh Kharisma Ratna Pramirtha [5] dengan judul "Model Pembelajaran Problem Solving Terhadap Kemampuan Menyelesaikan Soal Cerita Matematika bagi Siswa Tunanetra" dapat 
ditarik kesimpulan bahwa terdapat perbedaan pada kemampuan siswa dalam menyelesaikan soal cerita antara sebelum dan sesudah menggunakan problem solving. Hal tersebut juga terbukti saat peneliti melakukan penelitian dengan menggunakan pendekatan problem solving pada siswa kelas III SDN 1 Sayan.

Hasil uji hipotesis (uji-t) terhadap nilai pretest dan posttest yang diperoleh siswa kelas III SDN 1 Sayan menunjukkan bahwa terdapat perbedaan yang signifikan pada kemampuan siswa dalam menyelesaikan soal cerita. Kemampuan siswa dalam menyelesaikan soal cerita setelah diberikan perlakuan dengan pendekatan problem solving lebih baik dari pada kemampuan siswa sebelum diberikan perlakuan dengan pendekatan problem solving.

Penelitian Romika dan Yuli Amelia [8] yang berjudul Analisis Kemampuan Pemecahan Masalah Matematika Siswa pada Materi bangun Ruang Sisi Datar dengan Teori Van Hiele menunjukkan hasil bahwa tingkat kemampuan siswa di SD dalam pembelajaran mencapai tingkat yang tinggi yaitu memiliki nilai 81-100 (tergolong sangat tinggi)adalah 13 orang yaitu sebesar 54,16\%, nilai 61-80 (tergolong tinggi) 2 peserta didik sebesar 8,3\%, yang memiliki nilai dari 41-60 (tergolong cukup) adalah 2 peserta didim yaitu sebesar $8,3 \%$. Peserta didik yang memiliki nilai 21-40 (tergolong rendah) ada 4 peserta didik yaitu 16,6\%, dan yang terakhir nilai 0-20 (tergolong sangat rendah) adalah 3 peserta didik yaitu sebesar $12,5 \%$ siswa tidak memiliki nilai. Sesuai hasil yang telah diperoleh dapat menyimpulkan bahwa siswa di SD memiliki kemampuan pemecahan masalah yang tinggi dengan 15 atau $62,4 \%$ siswa telah bisa menyelesaikan soal tes, siswa-siswa tersebut juga memahami dengan baik apa yang ditampilkan dari soal tes yang diberikan.

\section{KESIMPULAN DAN SARAN}

Berdasarkan hasil analisis data yang dilaksanakan melalui penelitian dengan judul "Analisis Kemampuan Dalam Menyelesaikan 
Soal Cerita Menggunakan Pendekatan Problem Solving pada Materi Perkalian Di Kelas III SDN 1 Sayan" peneliti membuat kesimpulan bahwa kemampuan awal siswa dalam menyelesaikan soal cerita sebelum diberikan perlakuan dengan pendekatan problem solving yangt terlihat dari hasil pretest tadalah terkategori rendah, hal tersebut menandakan bahwa siswa kesulitan dalam menyelesaikan soal cerita pada materi perkalian. Kemudian, kemampuan siswa dalam dalam menyelesaikan soal cerita setelah diberikan perlakuan dengan pendekatan problem solving yang dapat terlihat dari hasil posttest menunjukkan bahwa sebagian besar siswa tidak lagi kesulitan dalam menyelesaikan soal cerita pada materi perkalian. Dari hasil pretest dan postest siswa maka peneliti membuat kesimpulan akhir bahwa terdapat perbedaan yang signifikan pada kemampuan siswa menyelesaikan soal cerita pada materi perkalian antara sebelum dan setelah diberikan perlakuan dengan menggunakan pendekatan problem solving.

Berdasarkan hasil penelitian yang telah dilaksanakan, terdapat beberapa hal yang harus dikembangkan. Adapun berkaitan dengan hal tersebut, maka peneliti mengemukakan beberapa saran yaitu siswa yang memiliki kemampuan intelektual rendah sebaiknya diberikan perlakuan yang khusus supaya proses pembelajaran dapat lebih efektif dan kepada peneliti lainnya yang hendak melakukan penelitian dengan menerapkan pendekatan problem solving sebaiknya dapat melanjutkan pada materi yang lainnya dengan memperhatikan langkah-langkah pembelajaran dengan pendekatan problem solving. 


\section{DAFTAR PUSTAKA}

[1]. Mutaqin, E.J. 2017. Analisis Learning Trajectory Matematis dalam Konsep Perkalian Bilangan Cacah di Kelas Rendah Sekolah Dasar. Jurnal Riset Pedagogik. Vol 1, No 1. 19-33 Universitas Sebelas Maret

[2]. Dahar, Ratna Wilis. 2006. Teori-teori Belajar dan Pembelajaran. Bandung : Erlangga.

[3]. Solihatin, E. \& Raharjo.2006.Cooperative Learning Analisis Model Pembelajaran IPS. Jakarta : Bumi Aksara.

[4]. Depdiknas.2006. Standar Kompetensi dan Kompetensi Dasar.Jakarta : Pusat Kurikulum, Badan Penelitian dan Pengembangan Depdiknas.

[5]. Pramirtha, Kharisma Ratna. 2014. Model Pembelajaran Problem Solving Terhadap Kemampuan Menyelesaikan Soal Cerita Matematika Bagi Siswa Tunanetra. Jurnal Pendidikan Khusus. Surabaya : Fakultas Ilmu Pendidikan Universitas Negeri Surabaya.

[6]. Yarmayani, Ayu. 2016. Analisis Kemampuan Pemecahan Masalah Matematis Siswa Kelas XI IPA SMA Negeri 1 Kota Jambi.Tidak diterbitkan. Program Studi Pendidikan Matematika Universitas Batanghari : Jambi.

[7]. Dewi, Sutra Asoka. 2016. Analisis Kemampuan Menyelesaikan Soal Cerita Matematika Siswa Kelas VIII SMP Negeri 03 Tuntang Tentang Bangun Datar Ditinjau Dari Teori Van Hiele. Prosiding Seminar Naisonal Matematika X. Universitas Negeri Semarang

[8]. Romika dan Amalia, Yuli.2014.Analisis Kemampuan Pemecahan Masalah Matematika Siswa pada Materi Bangun Ruang Sisi Datar dengan Teori Van Hiele.Tidak diterbitkan. STKIP Bina Bangsa : Meulaboh Aceh. 